Journal of Telenursing (JOTING)

Volume 1, Nomor 2, Desember 2019

e-ISSN: 2684-8988

p-ISSN: 2684-8996

DOI: https://doi.org/10.31539/joting.v1i2.842

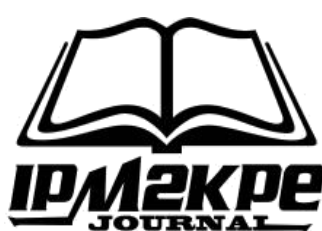

\title{
BELAJAR MELALUI VIDEO DI MEDIA SOSIAL DAPAT MENINGKATKAN KETERAMPILAN PEMASANGAN KATETER PADA MAHASISWA KEPERAWATAN
}

\author{
Dahrizal $^{1}$, Gita Putri Dewi ${ }^{1}$ \\ Politeknik Kesehatan Kementerian Kesehatan Bengkulu ${ }^{1,2}$ \\ dahrizal26@ymail.com ${ }^{1}$
}

\begin{abstract}
ABSTRAK
Tujuan penelitian ini adalah untuk menganalisis penggunaan video di media sosial sebagai media pembelajaran untuk keterampilan penempatan kateter pada siswa keperawatan. Desain penelitian adalah desain kuasi-eksperimental dengan pretestposttest dengan kontrol kelompok. Hasil penelitian menunjukkan bahwa ada perbedaan skor rata-rata keterampilan penempatan kateter pada kelompok intervensi sebelum diberi video dan 32,27 pemasangan kateter SOP, setelah diberi video dan penempatan kateter SOP menjadi 72,73. Hasil uji statistik independent sample t-test diperoleh nilai $\mathrm{p}$ $0,000(\mathrm{p} \leq \alpha 0,05)$. Simpulan, ada pengaruh penggunaan video di media sosial pada keterampilan penempatan kateter pada siswa keperawatan.
\end{abstract}

Kata kunci: Kateter, Media Pembelajaran, Video

\begin{abstract}
The purpose of this study was to analyze the use of video on social media as a learning medium for catheter placement skills in nursing students. The research design is a quasi-experimental design with pretest-posttest with group control. The results showed that there were differences in the average score of catheter placement skills in the intervention group before being given a video and 32.27 installation of a SOP catheter, after being given a video and SOP catheter placement being 72.73. Statistical test results of independent sample t-test obtained $p$ value of 0,000 ( $\alpha \alpha \alpha 0.05)$. Conclusion, there is an influence of the use of video on social media on catheter placement skills in nursing students.
\end{abstract}

Keywords: Catheter, Learning Media, Video

\section{PENDAHULUAN}

Pemasangan kateter merupakan tindakan keperawataan dengan cara memasukkan kateter ke dalam kandung kemih melalui uretra yang bertujuan untuk membantu memenuhi kebutuhan eliminasi dan sebagai pengambilan bahan pemeriksaan.Tindakan pemasangan kateter merupakan tindakan invasif yang dapat menimbulkan rasa nyeri, sehingga jika dikerjakan dengan cara yang keliru akan dapat menimbulkan kerusakan uretra yang permanen (Assessment, 2019).

Dalam era perkembangan ilmu pengetahuan dan teknologi yang begitu pesat, profesionalisme dosen tidak cukup hanya dengan kemampuan membelajarkan mahasiswa, tetapi juga mengelola informasi dan lingkungan untuk memfasilitasi 
kegiatan belajar, salah satunya dengan memperkaya sumber dan media pembelajaran (Daryanto, 2010). Dengan dikuasainya sumber dan media pembelajaran, dosen diharapkan mampu menjadi salah satu agen transfer ilmu bagi para mahasiswa (Putrianti, 2019).

Metode pembelajaran pemasangan kateter biasanya menggunakan metode lama seperti SOP dan simulasi. Hal ini juga dijelaskan oleh (Villanueva \& Hemstreet, 2008) metode pembelajaran pemasangan kateter secara konvensional (simulasi dan SOP) memberikan hasil teknik pemasangan yang kurang baik. Hal ini sering memberikan hasil pemasangan kateter urine yang jelek dan menjadi penyulit dalam melancarkan pengeluaran urine 24 jam pada pasien yang membutuhkan.

Video pembelajaran merupakan salah satu jenis media pembelajaran yang mengkombinasikan antara unsur suara dan gerak, sehingga dapat menggabarkan keadaan asli seperti dilapangan, media pembelajaran audiovisual menggunakan jenis video, video dapat menggambarkan suatu objek yang bergerak bersama-sama dengan suara alamiah atau suara yang sesuai.

Berbeda dengan yang diungkapkan Gaudin \& Chalies (2015) video pembelajaran tentang pemasangan kateter akan berpengaruh secara signifikan terhadap perolehan belajar mahasiswa dibandingkan dengan buku teks. Sebab video sebagai media pembelajaran mempunyai kelebihan yang salah satunya "bisa mengamati lebih dekat obyek yang bergerak dan gambar proyeksi bisa dihentikan untuk diamati dengan seksama".

Penggunaan video pada pemasangan kateter pada media sosial youtube maupun pengiriman melalui whatsapp dapat diakses dengan mudah dan tidak memerlukan waktu yang lama. Setelah menggunakan internet mahasiswa dapat mendowload videonya dan mempelajari secara individu atau berkelompok. Menurut LeMone \& Burke (2008) keuntungan yang didapatkan menggunakan youtube dalam pendidikan di keperawatan yaitu sebagai strategi untuk mendapatkan referensi dalam proses belajar mengajar, youtube sebagai alat motivasi belajar yang dapat melibatkan peserta didik dan mendukung gaya pembelajaran yang modern.

Dengan adanya stimulus menarik, maka peserta didik akan mudah dalam memproses informasi yang diterimanya, seperti yang diungkapkan oleh Desmita (2012) bahwa informasi dapat ditransfer menuju memori jangka pendek apabila informasi tersebut mendapat perhatian khusus. Hal penting dalam proses pengolah informasi adalah pemrosesan sendi-sendi (encoding) yang bermakna, yang membutuhkan proses perhatian ke sasaran. Proses penyandian ini merupakan inti dari proses belajar. Kurangnya perhatian menyebabkan informasi tersebut akan hilang. Stimulus tersebut dapat dikemas dalam suatu media yang dapat mendukung proses belajar dalam memahami konsep tanpa terbatas ruang dan waktu (Putrianti, 2019).

Sudjana \& Rivai (2011) mengemukakan manfaat media pembelajaran dalam proses belajar peserta didik, diantaranya motivasi belajar akan tumbuh dengan pembelajaran yang lebih menarik perhatian, memungkinkan peserta didik memahami makna dan menguasai bahan pembelajaran serta mencapai tujuan pembelajaran, peserta didik tidak bosan dan guru tidak kehabisan tenaga dengan adanya metode mengajar yang bervariasi dan tidak semata-mata komunikasi verbal oleh guru, peserta didik dapat lebih banyak melakukan kegiatan belajar dan beraktivitas seperti mengamati, melakukan, mendemonstrasikan, memerankan, dan lain-lain. 
Dalam membuat atau menetapkan media pembelajaran perlu memperhatikan kriteria pemilihan media. Arsyad (2009) menyampaikan kriteria yang harus diperhatikan diantaranya adalah kesesuaian dengan tujuan yang ingin dicapai, mendukung isi pelajaran, praktis, luwes dan bertahan, keterampilan guru dalam menggunakan, pengelompokkan sasaran,serta mutu teknis. Sedangkan Fathurrahman \& Sutikno (2007) menjelaskan beberapa faktor dan kriteria yang harus diperhatikan yaitu obyektifitas, kesesuaian program pengajaran, sasaran program, situasi dan kondisi, serta kualitas teknis.

Hasil survei Asosiasi Penyelenggara Jasa Internet Indonesia (APJII) menyebutkan bahwa pada tahun 2017, pengguna internet di Indonesia mencapai 143,26 Juta orang dari total populasi penduduk indonesia 262 juta orang. Hasil survei tersebut juga menunjukkan masyarakat berusia berusia 19-34 tahun yang menggunakan Internet di Indonesia yaitu sebesar $74,23 \%$. Komposisi penggunaan sosial media menurut jenis kelamin laki-laki 51,43\% sedangkan perempuan 48,57\%. Jumlah ini menunjukkan betapa besarnya media sosial sebagai media komunikasi dan penyebaran informasi tak terkecuali, persentase kepemilikan laptop/komputer sebanyak 25,72\% dan persentase kepemilikan smartphone/tablet sebanyak 50,08\%. Perangkat yang digunakan dalam mengakses internet laptop/komputer 4,49\% sedangkan smartphone/tablet 44,16\% dari data tersebut banyak penduduk menggunakan smartphone/tablet untuk penggunaan sosial media.

Pada hasil survey awal peneliti di Poltekkes Kemenkes Bengkulu didapatkan mahasiswa belajar menggunakan Standart Operasional Prosedur (SOP) saja sebanyak 67 mahasiswa didapatkan $45 \%$ ketrampilan mahasiswa dalam memasang kateter masih rendah salah satunya dilihat melalui ujian OSCA oleh karena itu didalam penelitian ini akan diujicobakan media pembelajaran berupa video pemasangan kateter sesuai dengan prosedur pemasangan kateter.

\section{METODE PENELITIAN}

Jenis penelitian adalah quasi eksperimen dengan desain one group pretest-postest with control grup. Penelitian ini dilakukan di Poltekkes Kemenkes Bengkulu pada tanggal 4-8 Maret 2019, pada kelompok intervensi diberikan link video pemasangan kateter di media sosial dan menonton video dengan durasi 16.33 menit yang ditonton sebanyak 2x dalam sehari, selama 2 hari berturut-turut, sedangkan kelompok kontrol diberikan Standar Operasional Prosedur pemasangan kateter. Populasi adalah seluruh mahasiswa keperawatan di Jurusan Keperawatan Poltekkes Kemenkes Bengkulu. Sampel diambil menggunakan teknik simple random sampling sebanyak 30 responden.

\section{HASIL PENELITIAN}

Tabel. 1

Karakteristik Responden Berdasarkan Gambaran Umur

\begin{tabular}{ccc}
\hline Karakteristik & Kontrol & Intervensi \\
\hline Mean & 18,67 & 18,60 \\
Median & 19,00 & 19,00 \\
SD & 0,488 & 0,507 \\
Min-Maks & $18-19$ & $18-19$ \\
CI for Mean 95\% & $18,40-18,94$ & $18,32-18,88$ \\
\hline
\end{tabular}


Berdasarkan tabel 1 hasil penelitian mengungkapkan karakteristik responden dalam penelitian ini dilihat dari umur. Pada umur responden kelompok intervensi rata-rata umur responden adalah 18,60 tahun dengan standar deviasi 0,507, dengan umur minimal 18 tahun dan umur maksimal 19 tahun. Dari hasil estimasi interval dapat disimpulkan bahwa 95\% diyakini rata-rata umur responden 18,32-18,88 atau 19 tahun. Sedangkan pada kelompok kontrol rata-rata umur responden adalah 18,67 tahun dengan standar deviasi 0,488, dengan umur minimal 18 tahun dan umur maksimal 19 tahun. Dari hasil estimasi interval dapat disimpulkan bahwa 95\% diyakini rata-rata usmur responden 18,40-18,94 atau 19 tahun.

Tabel. 2

Gambaran Rata-Rata Skor Keterampilan Pemasangan Kateter Sebelum dan Sesudah pada Kelompok Intervensi dan Kelompok Kontrol

\begin{tabular}{ccc}
\hline $\begin{array}{c}\text { Rata-Rata Skor Keterampilan } \\
\text { Pemasangan Kateter }\end{array}$ & Kontrol & Intervensi \\
\hline Sebelum & 37,40 & 32,27 \\
Mean & 39,00 & 33,00 \\
Median & 9,797 & 7,196 \\
SD & $20-61$ & $23-44$ \\
Min-Maks & $31,97-42,83$ & $28,28-36,25$ \\
CI for Mean 95\% & 57,73 & 72,73 \\
Sesudah & 59,00 & 74,00 \\
Mean & 8,722 & 10,780 \\
Median & $41-78$ & $60-95$ \\
SD & $52,90-62,56$ & $66,76-78,70$ \\
Min-Maks & & \\
CI for Mean 95\% & &
\end{tabular}

Berdasarkan tabel 2 didapatkan hasil analisis rata-rata nilai responden sebelum diberikan video pemasangan kateter di media sosial dan SOP untuk kelompok intervensi adalah 32,27 dengan standar deviasi 7,196 dan median 33,00. Nilai keterampilan pemasangan kateter terendah 23 dan nilai tertinggi 44. Dari hasil estimasi interval dapat disimpulkan bahwa 95\% diyakini rata-rata keterampilan pemasangan kateter berada pada rentang 28,28-36,25.

Sedangkan hasil analisa rata-rata nilai keterampilan pemasangan kateter sesudah diberikan video pemasangan kateter di media sosial dan SOP untuk kelompok intervensi adalah 72,73 dengan standar deviasi 10,780 dan median 74,00. Nilai keterampilan pemasangan kateter terendah 60 dan nilai tertinggi 95. Dari hasil estimasi interval dapat disimpulkan bahwa $95 \%$ diyakini rata-rata keterampilan pemasangan kateter berada pada rentang 66,76-78,70.

Hasil analisis rata-rata nilai responden sebelum diberikan SOP untuk kelompok kontrol adalah 39,00 dengan standar deviasi 9,797 dan median 37,40. Nilai keterampilan pemasangan kateter terendah 20 dan nilai tertinggi 61. Dari hasil estimasi interval dapat disimpulkan bahwa 95\% diyakini rata-rata keterampilan pemasangan kateter berada pada rentang 31,97-42,83.

Sedangkan hasil analisa rata-rata nilai keterampilan pemasangan kateter sesudah diberikan SOP untuk kelompok kontrol adalah 57,73 dengan standar deviasi 8,722 dan median 59,00. Nilai keterampilan pemasangan kateter terendah 41 dan nilai tertinggi 78. Dari hasil estimasi interval dapat disimpulkan bahwa $95 \%$ diyakini rata-rata keterampilan pemasangan kateter berada pada rentang 52,90-62,56. 
Pada uji kenormalan (shapiro-walk) pretest keterampilan pemasangan kateter dengan $p$ value 0,083 sedangkan uji kenormalan posttest keterampilan pemasangan kateter dengan $p$ value 0,330, sehingga dapat disimpulkan bahwa data berdistribusi normal. Hasil uji kesetaraan menunjukkan tidak ada perbedaan signifikan antara masing-masing variabel dengan $p$ value $>0,05$.

\section{Analisis Bivariat}

Berdasarkan uji kenormalan dengan menggunakan uji shapiro-wilk didapatkan hasil data yang di olah berdistribusi normal $(\mathrm{p}>0,05)$. Sehingga uji yang dilakukan yaitu uji t-test independent sample pada a 5\%. Untuk melihat perbedaan rata-rata keterampilan pemasangan kateter pada kelompok intervensi dan kelompok kontrol, apabila $\mathrm{p}<0,05$ maka ada pengaruh penggunaan video di media sosial terhadap keterampilan pemasangan kateter pada mahasiswa keperawatan.

Tabel. 3

Perbedaan Rata-Rata Nilai Keterampilan Pemasangan Kateter Sebelum dan Sesudah pada Kelompok Intervensi dan Kelompok Kontrol

\begin{tabular}{|c|c|c|c|c|c|c|c|c|}
\hline \multirow[t]{2}{*}{$\begin{array}{c}\text { Keterampilan } \\
\text { pemasangan } \\
\text { kateter }\end{array}$} & \multicolumn{4}{|c|}{ Kelompok Intervensi } & \multicolumn{4}{|c|}{ Kelompok Kontrol } \\
\hline & Mean & $\Delta$ mean & SD & $P$ value & Mean & $\begin{array}{c}\Delta \\
\text { mean }\end{array}$ & SD & $P$ value \\
\hline Sebelum & 32,27 & & 7,196 & & 37,40 & & 9,797 & \\
\hline Sesudah & 72,73 & 40,467 & 10,780 & 0,000 & 57,73 & 20,333 & 8,722 & 0,000 \\
\hline
\end{tabular}

*paired $t$-test

Berdasarkan tabel 3 didapatkan hasil analisis untuk kelompok intervensi sebelum diberikan video dan SOP pemasangan kateter adalah 32,27, setelah diberikan video dan SOP pemasangan kateter adalah 72,73. Terdapat perbedaan selisih 40,467. Hasil uji statistik menunjukkan $\mathrm{p}=0,000<0,05$ sehingga dapat disimpulkan ada beda rata-rata keterampilan pemasangan kateter pada mahasiswa keperawatan sebelum dan sesudah diberikan video dan SOP pemasangan kateter.

Sementara rata-rata keterampilan pemasangan kateter pada kelompok kontrol sebelum diberikan SOP pemasangan kateter adalah 37,40 dan setelah diberikan SOP pemasangan kateter adalah 57,73. Terdapat perbedaan selisih 20,333. Hasil uji statistik menunjukkan nilai $\mathrm{p}=0,000<0,05$ sehingga dapat disimpulkan ada beda rata-rata keterampilan pemasangan kateter pada mahasiswa keperawatan sebelum dan sesudah diberikan SOP pemasangan kateter.

Tabel. 4

Perbedaan Rata-Rata nilai Keterampilan Pemasangan Kateter pada Kelompok Intervensi dan Kelompok Kontrol Setelah Diberikan Intervensi

\begin{tabular}{cccccc}
\hline Kelompok $(\mathrm{n}=30)$ & \multicolumn{5}{c}{ Keterampilan Pemasangan Kateter } \\
\cline { 2 - 6 } & Mean & SD & SE & $95 \%$ CI & P value \\
\hline Intervensi & 40,46667 & 10,336 & 4,087 & $11,75-28,50$ & 0,000 \\
Kontrol & 20,3333 & 11,992 & 4,087 & $11,75-28,51$ & 0,000 \\
\hline
\end{tabular}


Berdasarkan tabel 4 Hasil uji statistik independentsampelt-test didapatkan nilai $p$ value $0,000(\mathrm{p} \leq \alpha 0,05)$. Sehingga dapat disimpulkan bahwa ada pengaruh penggunaan video dimedia sosial terhadap keterampilan pemasangan kateter pada mahasiswa keperawatan.

\section{PEMBAHASAN}

\section{Perbedaan Rata-Rata Skor Keterampilan Pemasangan Kateter Sebelum dan Sesudah Intervensi}

Hasil analisa rata-rata nilai keterampilan pemasangan kateter kelompok kontrol sebelum diberikan SOP pemasangan kateter adalah 37,40. Sedangkan rata-rata nilai keterampilan pemasangan kateter setelah diberikan SOP pemasangan kateter adalah 57,73. Berdasarkan hasil tersebut dapat terlihat bahwa nilai meanketerampilan pemasangan kateter sebelum dan sesudah diberikan SOP pemasangan kateter lebih besar dibandingkan dengan sebelum diberikan SOP pemasangan kateter.

Hasil analisa rata-rata nilai keterampilan pemasangan kateter kelompok intervensi sebelum diberikan video dan SOP pemasangan kateter di Poltekkes Kemenkes Bengkulu adalah 32,27. Sedangkan rata-rata nilai keterampilan pemasangan kateter setelah diberikan video dan SOP pemasangan kateter adalah 72,73. Berdasarkan hasil tersebut dapat terlihat bahwa nilai meanketerampilan pemasangan kateter sebelum dan sesudah diberikan video dan SOP pemasangan kateter lebih besar dibandingkan dengan sebelum diberikan video dan SOP pemasangan kateter.

Hasil analisis tersebut dapat disimpulkan bahwa terdapat perbedaan yang bermakna secara signifikan terhadap keterampilan pemasangan kateter kelompok kontrol menggunakan SOP pemasangan kateter dan kelompok intervensi menggunakan video dan SOP pemasangan kateter.

Hal ini sejalan dengan penelitian Asri et al., (2009) berdasarkan hasil analisis regresi linier ganda pada kelompok eksperimen terdapat pengaruh media pembelajaran video terhadap hasil belajar keterampilan pemasangan infus pada mahasiswa S1 keperawatan. mahasiswa yang mendapatkan media pembelajaran video rata-rata memiliki keterampilan memasang infus $(b=6.64, p=0,023)$ lebih tinggi dari pada teks dan gambar. Sedangkan pada kelompok kontrol tidak terdapat pengaruh gaya belajar terhadap peningkatan keterampilan pemasangan infus. Mahasiswa dengan gaya belajar auditorial rata-rata memiliki keterampilan pemasangan infus $(b=6.38, p=0,111)$ lebih tinggi dari pada visual.

Dari hasil analisa regresi linier ganda adalah terdapat pengaruh penggunaan media belajar video dan gaya belajar mahasiswa terhadap hasil belajar keterampilan pemasangan infus, pengaruh tersebut secara statistik signifikan $(b=6.64, p=0,041)$. Dengan hasil analisis tersebut dengan media pembelajaran video mahasiswa lebih mudah memahami tentang gambaran yang jelas terhadap informasi yang disampaikan dan dapat mengulangi lagi gerak-gerakan yang dipahami oleh mahasiswa.

Hasil penelitian ini juga didukung dengan penelitian Agustin (2013) berdasarkan hasil analisis pada kelompok A yang mendapat media fantom dengan nilai minimal 58, nilai maksimal 90 dan nilai rata-rata 66,9 sedangkan pada kelompok B yang mendapat media video dengan nilai minimal 58, nilai maksimal 100 dan rata-rata nilai 87,4 setelah dilakukan uji t test dengan $\alpha=0,05$ dengan $p$ value 0,00 terdapat perbedaan signifikan antara metode pembelajaran media fantom dan media video. 
Sejalan dengan penelitian Berlina et al., (2014) berdasarkan hasil analisis diperoleh nilai $p$ value $0,00<\alpha=0,05$, hal ini bahwa terdapat perbedaan yang signifikan antara kelompok yang diajar menggunakan media video dan flipchart dalam pembelajaran pemasangan kateter wanita. Kelompok yang diajarkan menggunakan media video lebih efektif dibandingkan dengan kelompok yang diajar menggunakan media flipchart.

Penggunaan video dimedia sosial salah satunya dapat dipengaruhi oleh koneksi internet, koneksi internet yang lambat dapat mempengaruhi kualitas penontonan video. Hal ini tidak sejalan dengan penelitian Iwantara (2014) berdasarkan hasil analisis statistik deskriptif diketahui pada kelompok intervensi skor pretest pemahaman konsep siswa yang menggunakan media rill dengan rata-rata 19,33 dan nilai rata-rata posttest 44,33 sedangkan pada kelompok kontrol skor pretest pemahaman konsep siswa yang menggunakan media video youtube dengan rata-rata 19,91 dan nilai rata-rata posttest 44,12 . Berdasarkan data ini didapatkan bahwa data rata-rata posttest pemahaman konsep siswa yang paling besar terdapat pada kelompok intervensi yaitu media rill.

\section{Perbedaan Selisih Keterampilan Pemasangan Kateter Sebelum dan Sesudah Diberikan Video dan SOP Pemasangan Kateter pada Kelompok Intervensi dan sop pada Kelompok Kontrol}

Dari hasil penelitian yang telah dilakukan peneliti didapatkan hasil dan telah telah dilakukan uji independent sample $t$ test untuk mengetahui perbedaan rata-rata, didapatkan hasil selisih nilai kelompok intervensi menunjukkan nilai $p$ value 0,000 ( $\mathrm{p} \leq$ $\alpha 0,05$ ) sedangkan selisih dari kelompok kontrol menunjukkan nilai $p$ value 0,000 ( $\mathrm{p} \leq \alpha$ 0,05 ) sehingga dapat disimpulkan ada perbedaan nilai rata-rata kelompok intervensi dan kelompok kontrol. maka Ho ditolak, artinya ada perbedaan bermakna antara kelompok intervensi menggunakan video dimedia sosial dengan SOP pemasangan kateter dan kelompok kontrol menggunakan SOP pemasangan kateter. Penelitian yang dilakukan okel Putrianti (2019) menunyatakan bahwa penggunaan media pembelajaran dalam pengajaran pemasangan kateter wanita sangat berpengaruh bagi daya tangkap mahasiswa.

Menurut penelitian Wibowo (2016) analisa yang dilakukan menggunakan uji $t$ test pairedPenggunaan media video pembelajaran dapat digunakan untuk meningkatkan hasil belajar siswa pada mata pelajaran IPS tentang bentuk muka bumi dan aktivitas penduduk Indonesia karena peningkatan hasil belajar kelas intervensi lebih tinggi dari pada kelas kontrol. Pada pre testdan post test kelas intervensi mengalami peningkatan sebesar 10,82\%, sedangkan pada kelas kontrol mengalami peningkatan sebesar 8,4\%. Hasil belajar antara kelas intervensi dengan kelas kontrol menunjukan adanya perbedaan. Nilai rata-rata kelas intervensi yang menggunakan media video pembelajaran memiliki nilai post test $80,62 \%$ sedangkan pada kelas kontrol nilai ratarata post test sebesar 58,33\%. Perbedaan dari kelas tersebut menunjukan bahwa penggunaan media video pembelajaran lebih efektif dibandingkan dengan model konvensional.

Hasil penelitian ini sejalan dengan penelitian Kustanti (2013) analisa yang didapatkan menggunakan uji $t$ test menunjukkan nilai pre test terdapat perbedaan ratarata kompetensi pemasangan kateter urin antara kelompok modul dan modul dengan video sebelum perlakuan $\mathrm{P}=0.686$. sedangkan hasil post test menunjukkan rata-rata kopetensi pemasangan kateter urin lebih tinggi dan secara statistik signifikan pada kelompok modul dengan video dari pada modul saja setelah diberikan perlakuan 
$\mathrm{P}=0.011$. Jadi penambahan metode video kepada modul efektif untuk meningkatkan kompetensi pemasangan kateter.

Penggunaan video sangat baik dipergunakan untuk membantu pembelajaran, terutama untuk memberikan penekanan pada materi yang sangat penting untuk diketahui oleh peserta didik. keuntungan dari media pembelajaran keterampilan keperawatan video adalah : 1) Video mampu menggambarkan keadaan nyata/ menyerupai keadaan sebenarnya, 2) Video bersifat dinamis sehingga merangsang rasa dan mudah memberikan kesan, 3) Video memungkinkan penerangan berulang-ulang, 4) Video mampu meraih emosi seseorang sehingga seseorang tidak langsung mwngubah sikap seseorang dengan lebih mudah. Penggunaan media pembelajaran yang lebih visual dan memperbanyak pengalaman, agar lebih memudahkan siswa dalam mencapai hasil pembelajaran.

Video pembelajaran merupakan salah satu jenis media pembelajaran yang mengkombinasikan antara unsur suara dan gerak, sehingga dapat menggabarkan keadaan asli seperti dilapangan, media pembelajaran audiovisual menggunakan jenis video, video dapat menggambarkan suatu objek yang bergerak bersama-sama dengan suara alamiah atau suara yang sesuai.

Pernyataan Sardiman (2010) yang mengatakan bahwa media video merupakan media pendidikan yang memiliki unsur audio dan visual, visual dan suara yang sangat dominan, sehingga dapat memberikan gambaran jelas terhadap informasi yang disampaikan betul-betul terbukti. Hasil analisis data kelompok yang diajar menggunakan media video dalam pembelajaran pemasangan kateter wanita menujukkan nilai rata-rata yang sangat tinggi. Hal ini membuktikan bahwa media video dapat digunakan sebagai alternatif media pembelajaran dalam kompetensi pemasangan kateter wanita.

Hasil penelitian tersebut juga membuktikan bahwa media pembelajaran memang dapat meningkatkan ketercapaian kompetensi di kelas. Hal tersebut juga selaras dengan apa yang disampaikan oleh Sanaky \& Hujair (2011) bahwa tujuan media pembelajaran sebagai alat bantu pembelajaran, adalah sebagai berikut: a) mempermudah proses pembelajaran di kelas, b) meningkatkan efisiensi proses pembelajaran, c) menjaga relevansi antara materi pelajaran dengan tujuan belajar, d) membantu konsentrasi pembelajaran dalam proses pembelajaran.

Dari uraian diatas maka dapat disimpulkan pembelajaran melalui video lebih efektif dibandingkan dengan membaca SOP dalam meningkatkan keterampilan pemasangan kateter pada mahasiswa keperawatan, dengan pembelajaran melalui video akan menstimulasi pada memori sensorik (visual dan aural) secara bersamaan sehingga meningkatkan retensi informasi kedalam memori jangka panjang.

\section{SIMPULAN}

Rata-rata responden kelompok intervensi berusia 18,60 tahun, sedangkan kelompok kontrol berusia 18,67 tahun.

Ada beda rata-rata skor nilai keterampilan pemasangan kateter pada kelompok intervensi sebelum dan setelah diberikan video dan SOP pemasangan kateter.

Ada perbedaan rata-rata keterampilan pemasangan kateter kelompok intervensi dan kelompok kontrol terhadap keterampilan pemasangan kateter pada mahasiswa keperawatan. 


\section{SARAN}

Video di media sosial sebagai media pembelajaran yang modern yang dapat menambah wawasan atau media untuk membuat belajar menjadi menarik dan tidak membosankan, mahasiswa dapat lebih terampil dalam melakukan tindakan keperawatan.

\section{DAFTAR PUSTAKA}

Agustin, V. N. (2013). Peningkatan Aktivitas dan Hasil Belajar Siswa melalui Model Problem Based Learning (PBL). Journal of Elementary Education, 2(1), 39-43

APJII. (2017). Penetrasi dan Perilaku Pengguna Internet Indonesia. indonesia: www.teknopreneur.comwww.apjii.or.id

Arsyad, A. (2009). Media Pembelajaran. Jakarta: Rajawali Pers

Asri, Y., Murti, B., \& Haryati, S. (2009). Pengaruh Penggunaan Media Pembelajaran Video dan Gaya Belajar Mahasiswa terhadap Hasil Belajar Keterampilan Memasang Infus pada Mahasiswa S1 Keperawatan STIKES Kendedes Malang. Universitas Sebelas Maret Surakarta

Assessment, A. H. T. (2019). Ontario Health Technology Assessment Series: Intermittent Catheters for Chronic Urinary Retention: A Health Technology Assessment', Ontario Health Technology Assessment Series, 19(1), 1-153

Berlina, B., Wiryotinoyo, M., \& Damris, M. (2014). Pengembangan Media Berbasis Komputer untuk Pembelajaran Kimia Kelas XI pada Sekolah Menengah Atas. Tekno-Pedagogi, 4(2)

Daryanto, D. (2010). Media Pembelajaran Peranannya Sangat Penting dalam Mencapai Tujuan Pembelajaran, Yogyakarta: Gava Media

Desmita, D. (2012). Psikologi Perkembangan. Bandung: Remaja Rosdakarya

Fathurrahman, P., Sutikno, S. (2007). Strategi Belajar Mengajar. Bandung: Refika Aditama

Fitri, E. Y, M., \& Chairoel, L. (2019). Penggunaan Media Sosial Berdasarkan Gender terhadap Prestasi Belajar Mahasiswa. Jurnal Benefita, 1(1), 162. DOI: 10.22216/jbe.v1i1.3849

Gaudin, C., Chaliès, S. (2015). Video Viewing in Teacher Education and Professional Development: A Literature Review, Educational Research Review, 16, 41-67. doi: 10.1016/j.edurev.2015.06.001

Iwantara, I. W. (2014). Pengaruh Pengunaan Media Video Youtube dalam Pembelajaran IPA terhadap Motivasi Belajar dan Pemahaman Konsep Siswa. E Journal Program Pascasarjana Universitas Pendidikan Ganesha Program Studi IPA, 4

Kustanti, C. (2013). Perbedaan Efektivitas Penggunaan Media Belajar Video dan Modul Keterampilan Keperawatan dalam Pencapaian Kompetensi Pemasangan Kateter Urine. Jurnal Keperawatan Notokusumo, 1(1), 19-26

LeMone, P., \& Burke, B. (2008). Medical Surgical Nursing: Critical thinking in Client Care.(4th ed). Pearson Prentice Hall: New Jersey

Putrianti, B. (2019). Efektivitas Media Flipchart dan Video terhadap Pembelajaran Pemasangan Kateter Wanita pada Mahasiswa Semeter I. Jurnal Kesehatan Karya Husada, 7(1), 1-11

Sanaky, A. H., \& Hujair, H. (2011). Media Pembelajaran Buku Pegangan Wajib Guru dan Dosen. Yogyakarta: Kaukaba

Sardiman, A. M. (2010). Interaksi dan Motivasi Belajar Mengajar. Jakarta: Rajawali Pers

Sudjana, S., \& Rivai, R. (2011). Media Pengajaran. Bandung. Sinar Baru Algensindo 
Villanueva, C., \& Hemstreet, G. P. (2008) Difficult Male Urethral Catheterization: A Review of Different Approaches, International Braz J Urol, 34(4), 401-412. doi: $10.1590 / \mathrm{S} 1677-55382008000400002$

Wibowo, A. (2016). Pengembangan Media Buku Saku sebagai Sumber Belajar Siswa Kelas X Jurusan Jasa Boga pada Mata Pelajaran Ilmu Gizi Materi Pokok Zat Gizi Sumber Tenaga di Sekolah Menengah Kejuruan Negeri 3 Purworejo. Universitas Negeri Yogyakarta 